\title{
Revenue and Marketing Channel of Oyster Mushroom in Probolinggo District
}

\author{
Novita lidyana, Dyah Ayu Perwitasari, Mutimmah Rustianawati \\ Universitas Pancamarga Probolinggo \\ Email: dyahayu@upm.ac.id
}

\section{A R T I C L E I N F O}

Received:

9 January 2021

Revised:

4 March 2021

Accepted:

10 March 2021

\section{A B S T R A C T}

This research is a quantitative research. Primary data is the result of filling out questionnaires by all respondents, namely all mushroom farmers in Probolinggo. And secondary data in the form of all mushroom farmer data in Probolinggo with a total population of 60 mushroom farmers in Probolinggo. The selection of oyster mushroom farmer respondents was carried out using the census method. The samples in this study were all farmers who cultivated oyster mushrooms in Probolinggo Regency. The results of this study indicate that oyster mushroom farmers in Probolinggo use logs. By using this tool, it can increase the income of mushroom farmers. So that the oyster mushroom in Probolinggo is suitable to be used as a business / developed field. The marketing channel pattern of oyster mushrooms in Probolinggo uses two patterns. Namely the first pattern, mushroom farmers sell mushrooms to resellers, resellers will resell to retailers and reailers will sell again to end consumers. For the second pattern, mushroom farmers sell resellers, and resellers will sell directly to the final consumer. From the above analysis it can be concluded that the second channel is more profitable for farmers in terms of income.

Keywords: Oyster Mushrooms, Marketing Channels, Revenue

Cite this as: Lidyana, N., Perwitasari, D. A., Rustianawati, M. (2020). Revenue and Marketing Channel of Oyster Mushroom in Probolinggo District. Wiga : Jurnal Penelitian Ilmu Ekonomi, 11(1), 31-. https://doi.org/10.30741/wiga.v11i1.576

\section{INTRODUCTION}

In Indonesia, the economic activity of agricultural products is one of the leading sectors that must get priority in its development. High commodities must be developed in the agricultural sector, for example foodstuffs and ornamental plants. The purpose of developing these foodstuff products is to increase the level of community income and achieve food security. One of the foodstuff commodities developed and cultivated in Indonesia is the oyster mushroom Pleurotus ostreatus [Jacq. Ex. Fr.] Kummer). This oyster mushroom has high nutritional value and is a source of vegetable protein so it is safe for consumption by the public. This is because, in the cultivation 
process of oyster mushrooms, it uses relatively few chemicals and pesticides. As well as using wood waste as its growing medium.

One of the oyster mushroom producers in East Java Province is Probolinggo Regency. Mushroom farmers in Probolinggo Regency are still traditional, namely by using drum technology. So far, none of the farmers have used autoclave technology in cultivating this white oyster mushroom. Autoclave is a tool used to carry out sterilization so that the seeds are free from contaminants. So that by using this tool, it is hoped that it can increase crop yields and quality. With abundant yields, of course, it affects the income of mushroom farmers. Availability of capital, size of business scale, product selling price, labor, level of knowledge and experience can influence the income of mushroom farmers. There are many capital constraints in the field, which can hinder farmers from expanding their businesses. The role of the government and the private sector is needed, for example by providing capital assistance. With the help of capital, mushroom farmers are more optimal in cultivating mushrooms and followed by optimal yields as well.

Farmers' harvest must be marketed quickly and accurately. This is because the characteristics of oyster mushrooms are easily damaged, causing the weight of the oyster mushrooms to shrink in a relatively short period of time. Marketing and distribution constraints become more complex if the oyster mushroom farmers still insist on marketing their crops to marketing areas that are far from production centers, the condition of the oyster mushrooms becomes wilted and no longer fresh resulting in a drop in selling prices below the expected price, on the contrary, if marketing is carried out Around the production center, it means that the prevailing price is the lowest price as a result of the abundance of oyster mushrooms around the white oyster mushroom production centers. For that we need the right strategy in finding efficient marketing channels, so that the distribution and marketing constraints of white oyster mushroom farmers in Probolinggo Regency can be resolved properly.

Based on the background described above, the formulation of the problem in this study is knowing the income level of the oyster mushroom farming in Probolinggo Regency and what is the right channeling market form that can be chosen to overcome the obstacles of oyster mushroom farmers in Probolinggo Regency? The purpose of this study was to analyze the income of oyster mushroom farming in Probolinggo Regency and the marketing efficiency of oyster mushrooms in Probolinggo Regency. Fungi are species that are macroscopic in appearance like plants, but are not included in the plant kingdom. Mushrooms are separated into the kingdom of fungi (mushrooms). This is because there are special characteristics of fungi that are not owned by plants or there are characteristics of plants that are not owned by fungi. The structure of the cell wall of fungi is mostly composed of chitin, while in plants it is mostly cellulose, hemicellulose, and lignin. Fungi do not have true roots, stems, leaves and flowers. (Nugraha, Tatang. 2013).

The definition of farming is the entire organization of nature, labor, capital and management aimed at production in the agricultural field. The management of the organization itself is undertaken by a person or group of people, either genealogically, politically or territorially. In this case, farming includes notions ranging from simple forms, namely only to meet the needs of the family to the most modern form, namely seeking profit (Hernanto, 2016). Farming businesses managed by mushroom farmers are, of course, expected to benefit. This means that the profits derived from the total income obtained from the harvest after deducting the total costs incurred are positive. According to Soekartawi (1986), farm income includes all products that are sold, consumed by households, which are reused for seeds or stored in warehouses.

Benefits can be obtained by farmers, namely by marketing their crops to consumers. To obtain optimal profits, farmers must be able to reduce costs, one of which is marketing costs. This marketing cost can be reduced by the accuracy of farmers in choosing marketing channels. According to Limbong and Sitorus (1987), marketing is a series of process activities or activities aimed at distributing goods or services from the producer point to the consumer. Meanwhile, 
according to Limbong and Sitorus (1987), the trade system channel is an effort made to deliver goods and services from producers to consumers which involve trade system institutions. Marketing channels and marketing efficiency can be done using farmer's share analysis, marketing margin analysis and profit and cost analysis.

\section{METHOD}

This research was conducted in Probolinggo Regency in April 2020. The reason Probolinggo Regency was chosen as the research object is because Probolinggo Regency is one of the areas that has potential in the cultivation of oyster mushrooms. Data Collection Methods, primary data in this study is the result of filling out the questionnaire by all respondents, namely all mushroom farmers in Probolinggo Regency, secondary data in this study are all mushroom farmer data in Probolinggo Regency. The population of mushroom farmers in Probolinggo district is 60 farmers. The selection of oyster mushroom farmer respondents was carried out using the census method. The samples in this study were all farmers who cultivated oyster mushrooms in Probolinggo Regency.

Data Analysis Methods. Analysis of farm income, this analysis uses the R / C ratio. The R / C ratio is an analysis used to see the relative income of a business in one production period against the costs used. A business is declared feasible if the value of the $\mathrm{R} / \mathrm{C}$ ratio is $>1$. The higher the value of the $\mathrm{R} / \mathrm{C}$ ratio, the greater the profit. $\mathrm{R} / \mathrm{C}=$ total receipts/ total cash $=\mathrm{Q} . \mathrm{P} / \mathrm{BT}+\mathrm{BD}$. Where: $\mathrm{Q}$ $=$ Total Production in $\mathrm{Kg}, \mathrm{P}=$ Product Selling Price in IDR, BT $=$ cash costs in IDR, BD = Cost Calculated (Non-Cash Cost) in IDR.

The purpose of this analysis is to identify the marketing channels used to market products from producers to consumers or in other words to see the extent of the role of marketing agencies in maintaining products before they reach the end consumers. The level of marketing efficiency of white oyster mushrooms can use a marketing margin analyst. Marketing margin is obtained from the selling price minus the purchase price at each institutional level $\mathrm{M}_{\mathrm{i}}=\mathrm{H}_{\mathrm{ji}}-\mathrm{Hb}_{\mathrm{i}}$. Where: $\mathrm{Mi}=$ Marketing margin at level $-\mathrm{i}, \mathrm{H}_{\mathrm{ji}}=$ Market selling price at level $-\mathrm{i}, \mathrm{Hb}_{\mathrm{i}}=$ The market buying price at the level $-\mathrm{i}$. The amount of marketing margin can also be calculated by adding up marketing costs and the total profit of each agency $\mathrm{M}_{\mathrm{i}}=\mathrm{C}_{\mathrm{i}}+\pi_{\mathrm{i}} \cdot \mathrm{M}_{\mathrm{i}}=$ Purchase costs in the market level of $\mathrm{i}, \mathrm{C}_{\mathrm{i}}=$ Advantages of market trading in tier of $-\mathrm{i}, \pi_{\mathrm{i}}=$ Total marketing margin

Farmer 's Share Farmer's share is a comparison of the price received by farmers with the price received by the final consumer and expressed as a percentage (Limbong and Sitorus, 1987). FS = Pf/Pr x 100\%. Where: Fs = Farmer's share, Pf = Price at farmer level, Pr $=$ price at the consumer level

The ratio of profits and costs at each marketing agency is formulated as follows: Profit and Cost Ratio $=$ Total Profit in level $-\mathrm{i} /$ Total Cost in level $-\mathrm{i}$. Where: The profit $\mathrm{i}$ in level $-\mathrm{i}=$ the profit of the trading agency, Cost in level $-\mathrm{i}=$ cost of trade administration agency (IDR)

\section{RESULTS AND DISCUSSION}

To measure the evaluation of the production process activities in the agricultural sector in one period, an analysis of farm income is needed. This analysis can be used to measure the production process. The production process can be said to be successful or beneficial if the revenue is greater than the expenditure. These expenses are costs that are used in the production process, both cash and non-cash costs (calculated costs). 
To calculate the receipt of oyster mushrooms, it is obtained by multiplying the total production amount and the selling price per unit. Respondents of oyster mushroom farmers produced an average of 3,253 $\mathrm{kgs}$ with the number of logs owned as much as 8,133 logs. Oyster mushrooms are sold at an average price of IDR 13,000 per $\mathrm{kg}$, so the average revenue is IDR 42,293,333 in one production process (three months).

In Oyster Mushroom farming, the costs incurred come from cash costs and non-cash costs (calculated cost). Cash costs are costs directly used by farmers in the farming production process, such as the cost of procuring seeds, raw material costs and labor costs. Meanwhile, non-cash costs (calculated costs) are costs used for depreciation of equipment, buildings and use of labor in the family. The use of labor from within the family is assessed based on the prevailing wages in the community.

Table 2.Oyster Mushroom Farming Expenditure in Probolinggo Regency in One Production Process (3 months)

\begin{tabular}{|c|c|c|c|c|}
\hline $\begin{array}{l}\text { Expenditures for Farmers } \\
\text { Oyster mushroom }\end{array}$ & $\begin{array}{c}\text { Number } \\
\text { of } \\
\text { Products } \\
\text { Used }\end{array}$ & $\begin{array}{c}\text { Unit } \\
\text { price } \\
\text { (IDR) }\end{array}$ & $\begin{array}{l}\text { Total } \\
\text { IDR) }\end{array}$ & $\begin{array}{c}\% \\
\text { To } \\
\text { Total Cost }\end{array}$ \\
\hline \multicolumn{5}{|l|}{ Cash Costs } \\
\hline Mushroom F1 Seeds & 528,571 & 6.000 & 3.171 .426 & 12,64 \\
\hline Sawdust (sack) & 562,857 & 8.000 & 4.502 .856 & 17,94 \\
\hline Limestone $(\mathrm{kg})$ & 277,143 & 5.000 & 1.385 .715 & 5,52 \\
\hline Gypsum (kg) & 138,257 & 6.000 & 831.432 & 3,31 \\
\hline Bran (kg) & 148,5 & 4.000 & 594.000 & 2,23 \\
\hline Flour $(\mathrm{kg})$ & 156,429 & 4.000 & 1.095 .003 & 2,37 \\
\hline Heat-resistant plastic (kg) & 120,857 & 15.000 & 1.812 .855 & 7,22 \\
\hline Rubber bracelet (kg) & 6,8 & 15.000 & 102.000 & 0,41 \\
\hline Ring (buah) & 11571 & 100 & 1.157 .100 & 4,61 \\
\hline rubbing alcohol (bottle) & 13,857 & 6.000 & 83.142 & 0,33 \\
\hline Newspaper (kg) & 10,000 & 1.500 & 21.144 & 0,08 \\
\hline Sugar $(\mathrm{kg})$ & 10,571 & 11.000 & 116.281 & 0,46 \\
\hline TKL (HOK) & 240 & 20.000 & 4.800 .000 & 19,31 \\
\hline LPG (buah) & 100 & 17.500 & 1.750 .000 & 6,97 \\
\hline Total Cash Costs & & & 21.610 .945 & 86,15 \\
\hline \multicolumn{5}{|l|}{ Calculated Costs: } \\
\hline Depreciation of Equipment & & & 62.324 & 0,25 \\
\hline Depreciation of Buildings & & & 118.304 & 0,47 \\
\hline TKK (HOK) & & & 3.294 .643 & 17,14 \\
\hline Total Calculated Costs & & & 3.375 .271 & 13,85 \\
\hline Total Costs & & & 29.095 .216 & 100 \\
\hline
\end{tabular}

Source:

The Informations:

TKL $=$ Workers who come from outside the family

$\mathrm{TKD}=$ Workers who come from within the family

From the table above, it can be concluded that the use of total costs by oyster mushroom farmers in Probolinggo Regency is IDR 29,095,216 with the total logs owned by 8,133 logs. Cash costs used were IDR 21,610,945 (86.15\%) and non-cash costs (calculated costs) were IDR 3,225,147 (13.85\%). The largest cost allocation is the use of labor from outside the family, amounting to IDR $4,800,000(19.13 \%)$. Finding labor that can be used for oyster mushroom cultivation is very difficult in the study area and is offset by high wages. This is because there are jobs in the 
industrial sector, such as cigarette factories. It is difficult for oyster mushroom farmers to find labor from outside the district with minimal wages. For non-cash costs (calculated costs) by the oyster mushroom farmers, the equipment depreciation costs IDR 62,324 (0.25\%), building depreciation is IDR $118,304(0.47 \%)$ and labor from within the family is IDR 3,294,643 (13.13\%). Income on total costs using the log average was 8,133 with an average production of $3,523 \mathrm{kgs}$ of IDR 42,293,333. For income on cash costs amounting to IDR 21,619,945 from IDR 25,095,216 all the costs used in oyster mushroom farming in Probolinggo Regency. The amount of revenue and costs will get a ratio of revenue and costs $(\mathrm{R} / \mathrm{C}$ ratio) of 1.68 . This means that an additional fee of IDR 1,000 will get you IDR 1,680 in revenue.

Table 3. R / C Ratio and Oyster Mushroom Farming Income in Probolinggo Regency in One Production Process (3 months)

\begin{tabular}{lc}
\hline \multicolumn{1}{c}{ Information } & Total (IDR) \\
\hline Oyster Mushroom Farmers' Income & 42.293 .333 \\
Farming Costs: & \\
Cash & 21.619 .945 \\
Non Cash (Calculated) & 3.475 .271 \\
Total Cost of Farming & 25.095 .216 \\
Farm Income on Cash Costs & 20.673 .388 \\
Farm Income on Total Cost & 17.198 .117 \\
R/C Ratio of Cash Costs & 1,96 \\
R/C Ratio to Total Cost & 1,68 \\
\hline
\end{tabular}

\section{Source:}

From the table above, it can be concluded that the oyster mushroom farming in Probolinggo Regency is suitable for business because the value of the two R / C ratios is more than 1. A wellmanaged business greatly affects the increase in income that farmers will get. In addition, good marketing is needed, because mushrooms are perishable products. So the right marketing will make it easier to spend the harvest and provide maximum benefits to farmers. For this reason, farmers must choose the right and efficient marketing channels.

Marketing Channel is a route or series of intermediaries, both managed by marketers and independent in delivering goods from producers to consumers. This overcomes the gap of time, place and ownership that separates goods and services from people who need or want them (Tjiptono, Fandy, 2020). In this research, the marketing channel is that the oyster mushrooms produced by farmers can be sold and reach customers / consumers. In selling oyster mushrooms, mushroom farmers in Probolinggo Regency use marketing channels: suppliers, retailers and end consumers.

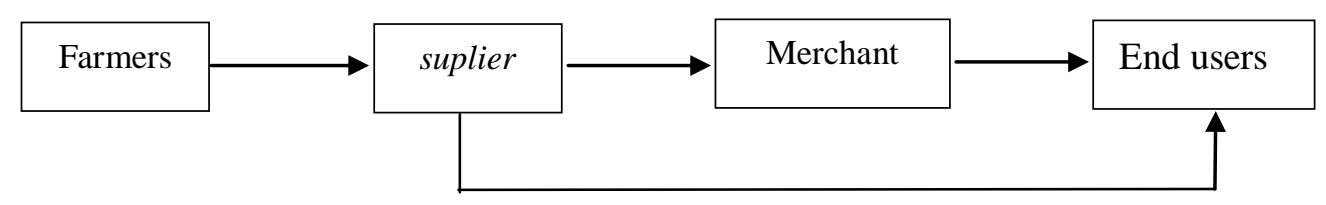

In the research area, farmers use two marketing patterns. In the first marketing pattern, it starts from farmers, suppliers, retailers, to the final consumer. As for the second pattern, the mushrooms produced by farmers are sold to suppliers and suppliers directly to the final consumer. Oyster mushroom farmers mostly use the second marketing pattern (75\%) of the 60 oyster mushroom farmer respondents in Probolinggo Regency.

The average production produced by oyster mushroom farmers in Probolinggo Regency is 3,523 kgs per one production process (three months). In the first channel pattern, oyster mushroom farmers in Probolinggo Regency sell oyster mushrooms to suppliers at a price of IDR 13,000 per 
$\mathrm{kg}$, then the supplier markets to retailers at a price of IDR 14,500 and the retailer sells to the final consumer for IDR 17,500. For the second channel, the oyster mushrooms are sold by farmers to suppliers at a price of IDR 13,000 per $\mathrm{kg}$, then the supplier sells oyster mushrooms to end consumers at a price of IDR 16,000 per kg.

For farmers, marketing has a function in understanding the needs and desires of consumers systematically. Marketing helps farmers establish mutually beneficial long-term relationships with target customers. Marketing facilitates the flow of products effectively and efficiently carried out by marketing agencies. The existence of this marketing agency will be involved in the process of delivering oyster mushrooms to consumers. This marketing function includes the exchange function, physical function, and facility function. In the marketing function that is usually performed by oyster mushroom farmers is a sales function. Where these farmers cultivate oyster mushrooms and sell their crops. The price received by farmers is based on the price prevailing in the market, usually there is an agreement between the farmer and the supplier. At the time of this study, the prevailing price was IDR $13,000 / \mathrm{kg}$.

Analysis on marketing efficiency using analysis of marketing margins, farmer's share, profit and cost ratios. Marketing margin is the difference between the price received by producer farmers and the price paid by the final consumer. What distinguishes the price level at the end consumer level will be influenced by the many marketing agencies involved in the marketing process, the length or shortness of the channels passed and the market distance, Nurlan F (1986). The more institutions involved in the distribution of commodities from producers to end consumers, the greater the price of these commodities with the prices paid by consumers.

Table 4. Marketing Margin of Oyster Mushroom Channels in Probolinggo Regency

\begin{tabular}{|c|c|c|c|c|}
\hline \multirow[t]{3}{*}{ Information } & \multicolumn{4}{|c|}{ Marketing Channel Patterns } \\
\hline & \multicolumn{2}{|r|}{1} & \multicolumn{2}{|c|}{2} \\
\hline & (IDR/kg) & $(\%)$ & (IDR/kg) & $(\%)$ \\
\hline \multicolumn{5}{|l|}{ Producers (Oyster $\quad$ Mushroom } \\
\hline \multicolumn{5}{|l|}{ Farmers): } \\
\hline Selling Price of Oyster Mushrooms & 13.000 & 74,29 & 13.000 & 81,25 \\
\hline Production cost & $6.645,47$ & 37,97 & $6.645,47$ & 41,53 \\
\hline Advantage & $6.354,53$ & 36,31 & 6.354 & 39,72 \\
\hline \multicolumn{5}{|l|}{ Supplier/ } \\
\hline Prices from Farmers & 13.000 & 74,29 & 13.000 & 81,25 \\
\hline \multicolumn{5}{|l|}{ Cost incurred: } \\
\hline Transport & 400 & 2,29 & 400 & 2,50 \\
\hline Selection of fresh mushrooms & 100 & 0,57 & 100 & 0,63 \\
\hline Mushroom packing & 150 & 0,86 & 150 & 0,94 \\
\hline Total Cost & 650 & 3,71 & 650 & 4,06 \\
\hline Selling prices by suppliers & 14.500 & 82,86 & 17.500 & 100 \\
\hline The benefits you get & 850 & 4,86 & 3.850 & 14,69 \\
\hline Margin & 1.500 & 8,57 & 4.500 & 18,75 \\
\hline \multicolumn{5}{|l|}{ Retailer Traders } \\
\hline Purchase prices from suppliers & 14.500 & 82,86 & & \\
\hline \multicolumn{5}{|l|}{ Cost incurred : } \\
\hline Levies on the market & 120 & 0,69 & & \\
\hline Mushroom packing & 130 & 0,74 & & \\
\hline Total Cost & 250 & 1,43 & & \\
\hline Selling prices by retailers & 16.000 & 91,43 & & \\
\hline The benefits you get & 1.500 & 8,57 & & \\
\hline Margin & 1.750 & 10,00 & & \\
\hline \multicolumn{5}{|l|}{ Consumer } \\
\hline Purchase price from retailers & 17.500 & 100 & 16.000 & 100,00 \\
\hline
\end{tabular}




\begin{tabular}{lllll}
\hline Total Marketing Costs & 900 & 5,1 & 650 & 4,06 \\
Total Profits & 2.350 & 13,4 & 2.350 & 14,69 \\
Total Margin & 2.250 & 18,60 & 3.000 & 18,75 \\
Profit / Cost Ratio & 2,61 & & 3,61 & \\
\hline
\end{tabular}

Source: researcher

In the table above, it can be seen in the first channel pattern of the marketing margin, namely IDR 2,250 per $\mathrm{kg}(18.60 \%)$, where farmers as producers of oyster mushrooms sell to suppliers / middlemen, then the middlemen are sold to retailers and retailers sell to the final consumer. The largest marketing margin is obtained at retailers of IDR 1,750 per $\mathrm{kg}(10.0 \%)$. For the cost benefit ratio, the second channel is worth more than the first marketing channel. The amount of the cost benefit ratio is 3.61, which means that each additional cost of one rupiah incurred will get a profit of IDR 3.61 .

To measure the operational efficiency of a marketing system is also to compare the price received by farmers (farmer's share) with the price paid by the end consumer. Expressed in percentage form.

Table 5. Farmer's Share, on Each Oyster Mushroom Marketing Channel in Probolinggo Regency

\begin{tabular}{lcc}
\hline \multicolumn{1}{c}{ Information } & Channel 1 & Channel 1 \\
\hline Farmer's share (\%) & 74,29 & 81,25 \\
Farmers' Profits (\%) & 36,31 & 39,72 \\
Trading Costs (\%) & 5,14 & 4,063 \\
Trade Organization Profits (\%) & 13,43 & 14,69 \\
\hline Prices at End Consumer Level (\%) & 100 & 100 \\
\hline
\end{tabular}

Source: by reseacher

Revenue from farmers in the first marketing channel is 74.29 percent, which comes from the selling price of retailers. For the second channel marketing pattern, oyster mushroom farmers get a farmer's share of 81.25 percent which is obtained from the selling price from retailers to the final consumer. So it can be concluded that oyster mushroom farmers should use the second channel pattern. Likewise with the profit ratio, the second channel pattern is bigger $(14.69 \%)$ than the one channel pattern (13.43\%).

\section{CONCLUSION}

Oyster mushroom farmers in Probolinggo Regency use logs of 8,133 with a production rate of $3,253 \mathrm{~kg}$ per one period (three months). In the income analysis, where the ratio between income and expenses ( $\mathrm{RC}$ ratio) is 1.96. This means that for each additional cost of IDR 1,000, you will receive an income of IDR 1,960. So it can be said that the oyster mushroom business is feasible and profitable to be used as a business / developed.

The pattern of marketing channels on oyster mushrooms in Probolinggo Regency, uses two patterns. Namely the first pattern, mushroom farmers sell mushrooms to resellers, resellers will resell to retailers and retailers will sell again to end consumers. For the second pattern, mushroom farmers sell resellers, and resellers will sell directly to the final consumer. From the analysis of the marketing margin, the marketing channel pattern is Rp. 3,250 (18.6\%) and the marketing margin in the second channel pattern is Rp. 3,000 (18.75\%). From the value of the ratio of profits and marketing costs of oyster mushrooms in Probolinggo Regency in the marketing channel pattern 1, it is obtained 2.61 and the second marketing channel pattern is 3.61. So it can be concluded that the value of the profit ratio is efficient, because the value is greater than one. At farmers' share, 
channel 1 pattern is 74.29 percent which comes from the selling price of retailers. For the pattern of marketing channels, two farmers's share is derived from the selling price of retailers to the final consumer. From the above analysis it can be concluded that the second channel is more profitable for farmers in terms of income.

There needs to be an institution that deals specifically for the post-harvest oyster mushrooms. Because when there is a big harvest, the price becomes cheaper and it doesn't even buy. For example, by empowering youth organizations by providing training on processed mushroom products. So that the oyster mushrooms produced by farmers can be distributed to these institutions, and can be processed directly to produce quality products.

\section{REFERENCE}

Cahyana, Y. A. (1997). Pembibitan dan Budidaya Jamur Tiram Putih. Papas Sinar Sinanti. Jakarta.

Dahl, Dale C. and Hammond J.W. (1992). Market and Proce Analysis. The Agriculture Industries. Mc. Graww-Hill Book Company, Inc.

Dania. (1998) . Teknik Budidaya Jamur Tiram Putih. Penebar Swadaya.

Direktorat Jendral Bina Produksi. (2007). Statistik Produksi Holtikultura. Pusat Data dan Informasi. Jakarta.

Kohls, R. L and J.N.Uhl. (1985). Marketing of Agriculture Product. Seventh Edition.

Purdue University. Maccmillan Publishing Company. New York.

Kotler, P. (2002). Manajemen Pemasaran. Edisi Milenium. Prenhallindo.

Muchrodi. (2001). Jamur Tiram Putih. Penebar Swadaya. Jakarta .

Purcell, Wayne. D. (1979). Agriculture Marketing System, Coordination. Cash

Sujarweni, V Wiratna. (2015). Metodologi Penelitian Bisnis dan Ekonomi. Pustaka Baru Press. Yogyakarta 